\title{
OROSZORSZÁG NEMZETKÖZI KÖZLEKEDÉSI INFRASTRUKTÚRÁINAK KÉNYSZEREI, GLOBÁLIS ÉS REGIONÁLIS SZEREPEI
}

\author{
(Russia's International Transport Infrastructure Constraints, \\ Global and Regional Roles)
}

ERDÖSI FERENC

\begin{abstract}
Kulcsszanak:
globalizáció regionalitás interkontinentális közlekedés gateway tranzit korridorok

A rendszerváltás Európa keleti felében a szintetikus állanok szétesésével, jó néhány ország önállóvá válásával äj térségi kereteket hozont létre a nemzeti és nemzetközi közlekedés müködtetéséhez. A cikk bemutatja, hogy az egykori Szovjetunió - továbbra is két földrészre kiterjedó - törzsét, az Orosz Föderációt az új helyzet milyen nagyszabásá közlekedési infrastruktúra-építésekre készteti egyfelöl annak érdekében, hogy külkereskedelnét ne akadályozza és drágísa az idegen kikötökre, illetve a tranzitutakra való ríutaltság, másfelöl, hogy a térségi kohéziót és a globális gazdaságba való bekapcsolódást egyaránt szolgáló transz-és interkontinentális folyosók létrejöjjenek.
\end{abstract}

A kelet-európai szláv térség több millió négyzetkilométernyi összefüggỏ fél kontinensén a korán polgárosodott és iparosodott, élénk kereskedelmet folytató NyugatEurópához képest elmaradott, kényszerszerüen túlnyomóan önellátásra berendezkedő államalakulatok számára a nemzetközi kereskedelembe való bekapcsolódást lehetóvé tevő meleg tengerpartok elérése félezer évre visszanyúló határozott törekvés. Attól függöen, hogy az észak-európai és délkelet-európaikisázsiai szomszédos (gyakran évszázadokig regionális középhatalmi pozíciót élvezỏ országokhoz (Svédország, Litvánia, illetve Törökország) milyen volt a keleti szláv államok (térbeli) viszonya, változott a különbözö tengerek, illetve az ottani kikötöhelyek tényleges használata.

A litván és svéd impérium sokáig elzárta az orosz állam elöl a Balti-tengert. Ezért Oroszország kénytelen volt a - hosszú téli jeges idöszak miatt csak korlátozottan használható és csupán az Észak-Drina folyón megközelíthetö - Fehér-tenger partján 1584-ben létrehozni Arhangelszk kikötöjét, mely a kiegyensúlyozott orosz-angol kapcsolatok hozadékaként számos kereskedöház telephelyévé vált (Johnson 1984).

\section{Oroszország történelmi tengeri kapui}

Oroszország történelmében az igazi „ablaknyitást” a nagyvilág felé Nagy Péter tette meg Szentpétervár alapításával. Oroszország első számú kikötőjének allokálása kényszerhelyzet következménye. Építésekor számolni kellett azzal, hogy a Finnöböl a törékeny fahajók számára a téli 3-4 jeges hónapban járhatatlan. 
Erdősi Ferenc: Oroszország nemzetközi közlekedési infrastruktúráinak kényszerei, globális és regionális szerepei. Tér és Társadalom, 19. 2005. 1. 1-20. p.

2 Erdösi Ferenc

TÉT XIX. évf. 2005

Az Orosz birodalom az egykor regionális hatalom Törökországgal évszázadokon keresztül hadban állt, hogy a Fekete-tenger északi partvidékét és a Kaszpitengerpart nagy részét uralja, és e tengereken szabadon közlekedhessen (beleértve a Földközi-tengerre való kijutást is a Boszporuszon és a Dardanellákon át). Annak ellenére, hogy Odesszát 1794-ben alapították, csak a megfelelő vasúti kapcsolatai létrejötte és az amerikaival vetélkedö ukrajnai árugabona termelés tömegessé válása után, a 19. sz. utolsó harmadától vette át fokozatosan az elsőszámú kereskedelmi kikötő szerepét. A Távol-Keleten Vlagyivosztok alapítása ugyan már 1860-ban megtörtént, azonban hadikikötö szerepköréhez csak meglehetösen szerény kereskedelmi kikötó társult. (A nyugat-szibériai gabonafelesleg piacot részben KözépÁzsiában, részben Európában talált, ezért a távoli Vlagyivosztokon keresztül kevés hagyta el Oroszországot [Antal 1983].)

A cári Orosz Birodalom kapcsolattartását Európával, a távolabbi tengerentúli területekkel a három balti ország (Észtország, Lettország, Litvánia) megszerzése (a 18. sz. végén/19. sz. elején), nagyban könnyítette. A vasút megépülése után Riga lett az egyik legfontosabb gabonaexport kikötö. A Barents-tenger parti Murmanszk jégmentessége csak 1916-tól, a hozzá vezetö vasút megnyitásától tudott értékesülni, de periférikus földrajzi helyzete miatt akkor is föként hadiflottabázisként. 1918-ban a balti államok önállóvá válását a szovjet kormányzat inkább csak politikai veszteségként élte meg, mivel a kikötők gazdasági jelentősége a szovjet birodalom teljes bezárkózottsága miatt meglehetősen alárendelt volt. 1940-töl - érdemileg 1944-től - a Szovjetunió számára a visszahódított Baltikum a Nyugat- és Észak-Európához való közelsége miatt eleinte elsösorban stratégiai szempontból volt értékes, később viszont már a külkereskedelem szempontjából is.

A második világháború utáni extenziv gazdaságfejlesztés során a politikai/társadalmi vonatkozásban rendkívül izolálódott Szovjetunió a beruházásokhoz szükséges eszközök, majd a népélelmezéshez szükséges gabona és más élelmiszerek behozatalára és ellentételezéseként világméretekben is igen nagy mennyiségü ásványi nyersanyag, energiahordozó kivitelére kényszerült. Az alapvetö szállitási mód - éppen az áruösszetétel jellegzetessége okán - a tengerhajózás lett. Azok a kikötök váltak a legfelkapottabbá, ahová a legnagyobb kapacitású vasutak és csővezetékek vezettek.

A német és az orosz érdekszféra metszéspontjában fekvő balti országok NyugatEurópa „kihelyezett tagozataként” a kelet-európai környezetben képesek voltak megörizni hagyományosan magasabb színvonalukat - nem kis részben éppen a mindenkori Orosz/Szovjet Birodalom számára betöltött kapufunkciójuk eredményeként. A Baltikum az önállóság és a Birodalomhoz tartozás idején egyaránt profitálni tudott a „küszöb-”, illetve „kapuhelyzetéböl” azzal, hogy - a saját fagymentes és Nyugat-Európához viszonylag közeli kikötökben szükölködö - Oroszország nem tudta nélkülözni külkereskedelméhez a jégmentes litván, a ritkán jeges lett és a jégtörőkkel télen is könnyen nyitva tartható észt kikötök használatát. 
Erdősi Ferenc: Oroszország nemzetközi közlekedési infrastruktúráinak kényszerei, globális és regionális szerepei. Tér és Társadalom, 19. 2005. 1. 1-20. p.

TÉT XIX. évf. 2005 曰 1

Oroszország nemzetközi ... 3

A Szovjetunió fennállásának utolsó évtizedében az összövetségi államhatárt több oldalon alkotó tengerpart ugyan számos változatban tette lehetóvé a külkereskedést, azonban az oroszországi illetékességủ tengeri szállítások $80 \%$-a a három balti tagállamon keresztül történt, mert a nyugati piacok elérése szempontjából ezek földrajzi helyzete a legkedvezöbb. Az olajkivitel a nyugat-szibériai mezökön fejlödő olajbányászat kiteljesedése után olyan méretüvé vált, hogy a kelet-közép-európai szocialista országok felé és azokból részben Nyugat-Európa felé közvetlenül vezetô csővezetékeken kívül már néhány balti kikötöbe, Ventspilsbe, Klaipeda-ba is megépítették a vezetékeket, de vasúton is millió tonna nagyságrendben érkezett olaj több baltikumi kikötőbe (Buchofer 1995).

\section{Az idegen kikötőkre való rászorultság gondjai a Szovjetunió megszünése után}

Geopolitikai és külgazdasági szempontból paradox módon éppen az egykori birodalmi politikát meghatározó Oroszország lett a Szovjetunió felbomlásának egyik (ha nem a legnagyobb) vesztese. Éppen akkor kellett szembenéznie földrajzi helyzetének a világgazdasági erőközpontokhoz képest periférikusabbá, északabbi fekvésủvé válásával, amikor a piacgazdaság melletti döntésekor a glóbuson való elhelyezkedés minósége eléggé nem értékelhető tényezönek bizonyult. 1991-ben Oroszország államterülete világra való nyitottságának mértéke, az azt meghatározó, a hajózás számára használható tengerpartok hossza és elhelyezkedése tekintetében máról-holnapra a Nagy Péter idejét idézỏ nehéz helyzetbe került.

Három szempontból is nagy veszteség érte Oroszországot:

- a kikötök száma és a rakodási kapacitás, továbbá

- a legfontosabb külkereskedelmi piacokhoz való térbeli viszony és a

- befolyásoló klimatikus viszonyok tekintetében.

A klimatikusan legkedvezőbb, a külpiacok eléréséhez is a legjobb fekvésü és legnagyobb kapacitású keleti- és fekete-tengeri kikötők maradtak kívül az Orosz Föderáció határain. A Keleti- (Balti-) tengeren orosz tulajdonban csak a Finn-öböl végi, hónapokig jeges, télen jégtörőkkel költségesen úgy-ahogy üzemeltethető Szentpétervăr, valamint a Litvánia és Lengyelország által közrefogott, izolált helyzetben levő exklávé, a Kalinyingrádi különleges terület partja maradt meg ( 1 . ábra).

Miközben lényegében megszüntek a világgazdaságba való integráció politikai akadályai, a kapcsolattartás, az árucsere közlekedési feltételei katasztrofális mértékben romlottak azáltal, hogy Oroszország kevés és rossz fekvésủ saját tengeri kikötövel rendelkezett, és az önállóvá lett szomszédos országoknak kiszolgáltatottá vált a tranzitszállitások tekintetében, ami jobb esetben csak a magas szálítási költségekben és kikötőhasználati, átrakási díjakban manifesztálódott, azonban nem ritka a politikai ,gonoszkodásig” elmenő akadékoskodás sem az oroszországi illetékességủ tranzittal kapcsolatban. 
Erdősi Ferenc: Oroszország nemzetközi közlekedési infrastruktúráinak kényszerei, globális és regionális szerepei. Tér és Társadalom, 19. 2005. 1. 1-20. p.

\section{1. ÁBRA}

Az Orosz Föderáció, valamint az önállóvá vált egykori szovjet tagállamok jelentôsebb kikötői

(The Most Important Harbours of the Russian Federation and the Independent, Sometime Soviet Member States)

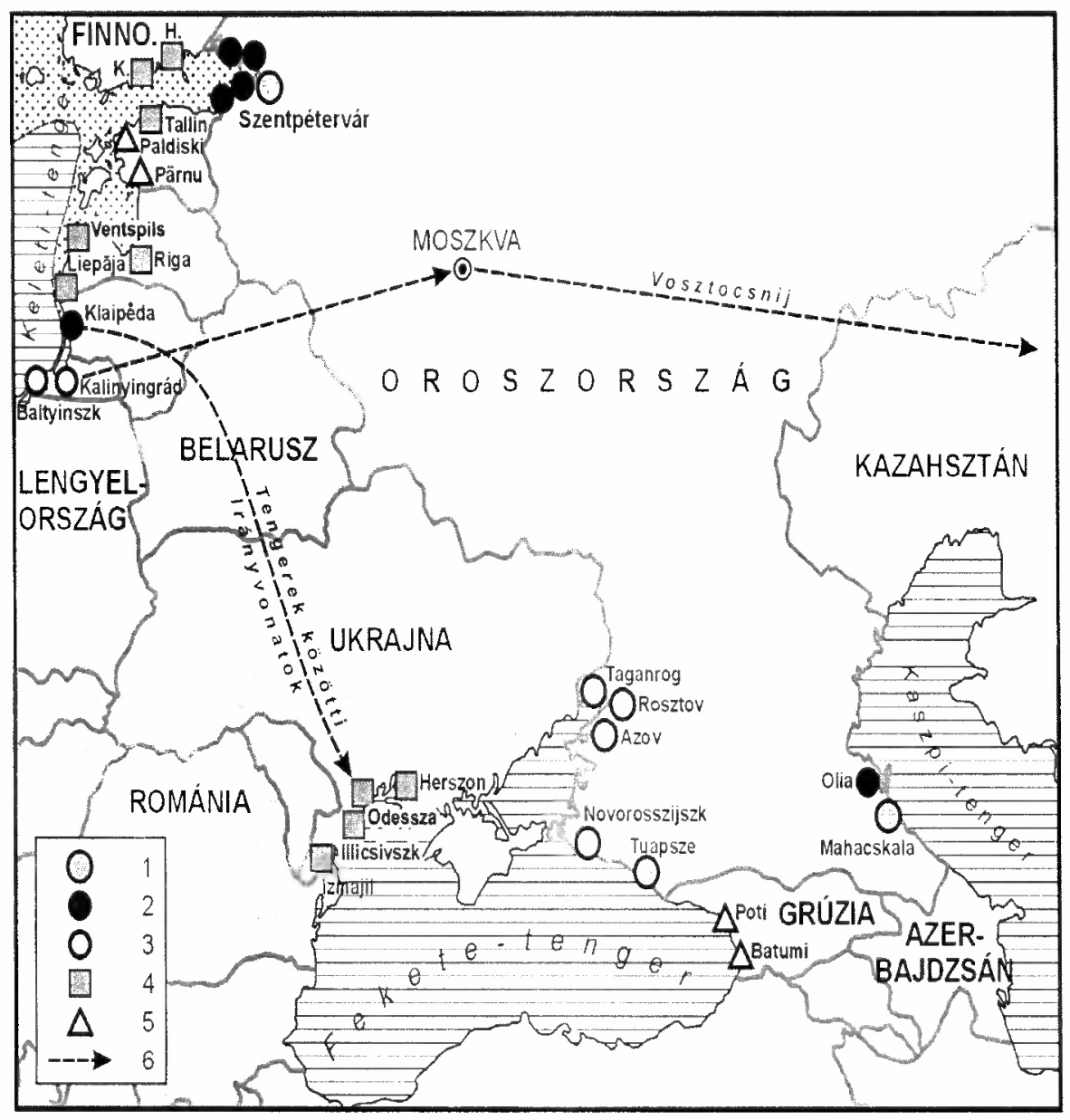

Jelmagyarázat:

1) az orosz területen maradt régebbi kikotök; 2) Oroszországban 1993 óta épüllvépülö új kikötök; 3) hadiból részlegesen kereskedelmire átalakított orosz kikötök; 4) Oroszország külgazdasága számára a legutóbbi idökig fontos baltikumi, ukrajnai és finn tranzitkikőtő́k; 5) egyéb baltikumi, ukrajnai és grúz kikőtök; 6) a tengerek (Keleti- és Fekete-tenger, Keleti-tenger és Csendes-óceán) közötti vasúti konténerszállítás irányvonatokkal.

\section{Szerkesztette: Erdősi.}


Erdősi Ferenc: Oroszország nemzetközi közlekedési infrastruktúráinak kényszerei, globális és regionális szerepei. Tér és Társadalom, 19. 2005. 1. 1-20. p.

Az utóbbiak közé tartozott többek között a Kalinyingrádi terület és az anyaország közötti szabad közlekedés elvitatása az EU-ba belépni készülö Litvánia mint tranzitország részéről. Ezért az 1990-es évek elején felmerült Litvánia Lengyelországon át történő megkerülésének terve (2. ábra), de az EU és NATO-tag Lengyelország diplomatikusan (természetvédelmi területének veszélyeztetettségére hivatkozva) elzárkózott a megvalósítástól (Buchofer 1998). Szerencsére e probléma a Litvániával folytatott tárgyalások után rendeződött, bár Litvánia ma is ellenőrzi az orosz szállítmányokat. Ukrajna pedig azzal hozta nehéz helyzetbe az Azovi beltenger orosz kikötőinek nemzetközi forgalmát, hogy az amúgy is keskeny kijáratban, a Kercsi-szorosban levő Tusla szigetet a saját területének nyilvánítva (amelynek 2004-ben katonai egységek állomásoztatásával is hangsúlyt adott) a sziget melletti tengeri útvonalakat is felségterületének tekintette, ezért Oroszország kénytelen lett volna a saját területén (a Tamanyi-félsziget nyugati földnyúlványát átvágva) hajózócsatornát ásni hajói szabad közlekedése érdekében (3. ábra). Időröl-idöre Oroszország szárazföldi kapcsolattartását Közép- és Nyugat-Európával, illetve a tengerentúllal nehezíti Ukrajna, ritkábban Beloruszia azzal, hogy különleges feltételek mellett és magas tranzitdíj fejében teszik lehetővé a tranzit olaj- és földgázvezeték üzemeltetését, vagy különféle legális és illegális módszerekkel sarcolják meg az orosz közúti és vasúti szállítmányokat.

Oroszország korszerütlen ipara reménytelenül összeomlott, elvesztette egykori piacait a szatellita országokban. A gazdaság, az államháztartás stabilizálásának egyetlen reális módja a világpiacon keresett energiahordozók, ásványi és más nyersanyagok, nehézvegyipari termékek exportjának lényeges növelése lehetett. Kiemelkedő szerepet szántak az olajkivitelnek. A prognózisok már az 1990-es évek elején azzal számoltak, hogy az Egyesült Államok olajimportjában a Közel-Keletet Oroszország váltja fel. Az olaj piacokra szállításához a Közép- és Nyugat-Európa felé kiépített csővezetékek kapacitása messze nem elegendö, más földrészekre, sőt a közeli Svédországba szállításhoz pedig kizárólag a tengerhajózás jöhet számításba. Azonban az Orosz Föderáció már az 1990-es évek elején szembesült azzal a súlyos logisztikai helyzettel, hogy tengeri külkereskedelmi forgalmának több mint a felét idegen - mindenekelött baltikumi, finnországi és kisebb részben ukrajnai - kikötökön, illetve az odavezetö tranzitútvonalakon kénytelen bonyolítani, ami évente 130-150 Mrd USD kiadással járt (Deeg 2001). 
Erdősi Ferenc: Oroszország nemzetközi közlekedési infrastruktúráinak kényszerei, globális és regionális szerepei. Tér és Társadalom, 19. 2005. 1. 1-20. p.

\section{2. ÁBRA}

A kalinyingrádi orosz exklávé közlekedési kapcsolata

Oroszország összefüggö területével

(The Communication Linkages between the Russian Enclave Kaliningrad and Russia's Main Territory)

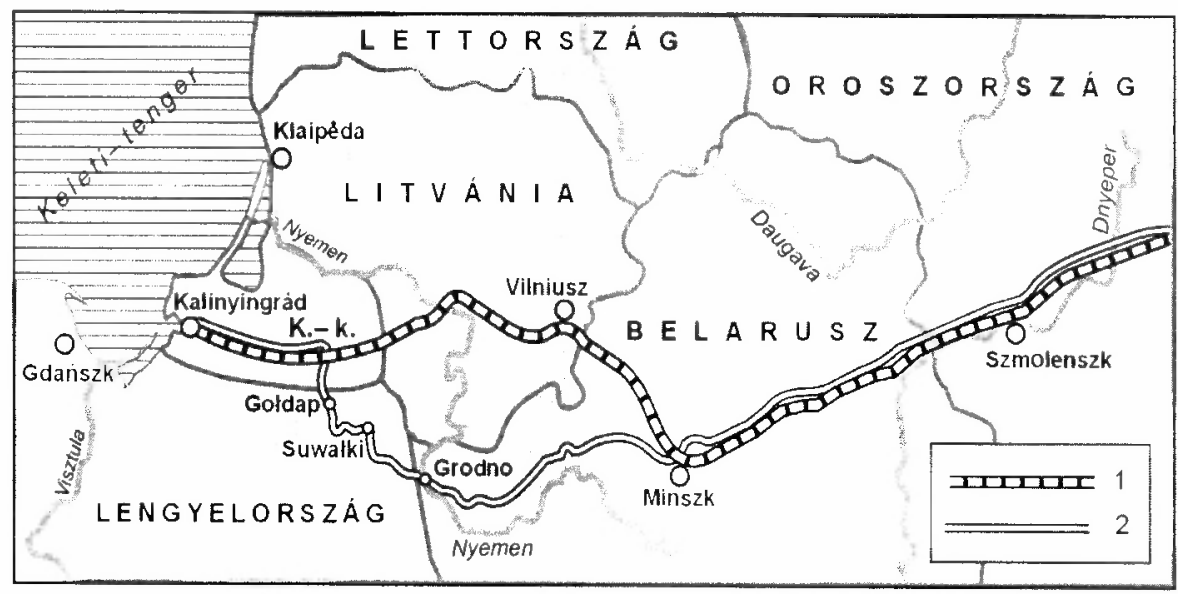

\section{Jelmagyarázat:}

1) a Kalinyingrád-Szmolenszk-Moszkva vasúti fövonal; 2) az oroszok által kért, Lengyelországon átvezetỏ (Kalinyingrád-Suvalki-Grodno-Minszk-Szmolenszk-Moszkva) és a lengyel kormány által elutasított fơút változat; K.-k.: Kalinyingrádi körzet.

Forrás: Buchofer 1998.

\section{3. ÁBRA}

A Kercsi-tengerszoros és a vitatott Tusla-sziget elhelyezkedése (The Location of the Kerch Strait and the Disputed Tusla Islands)

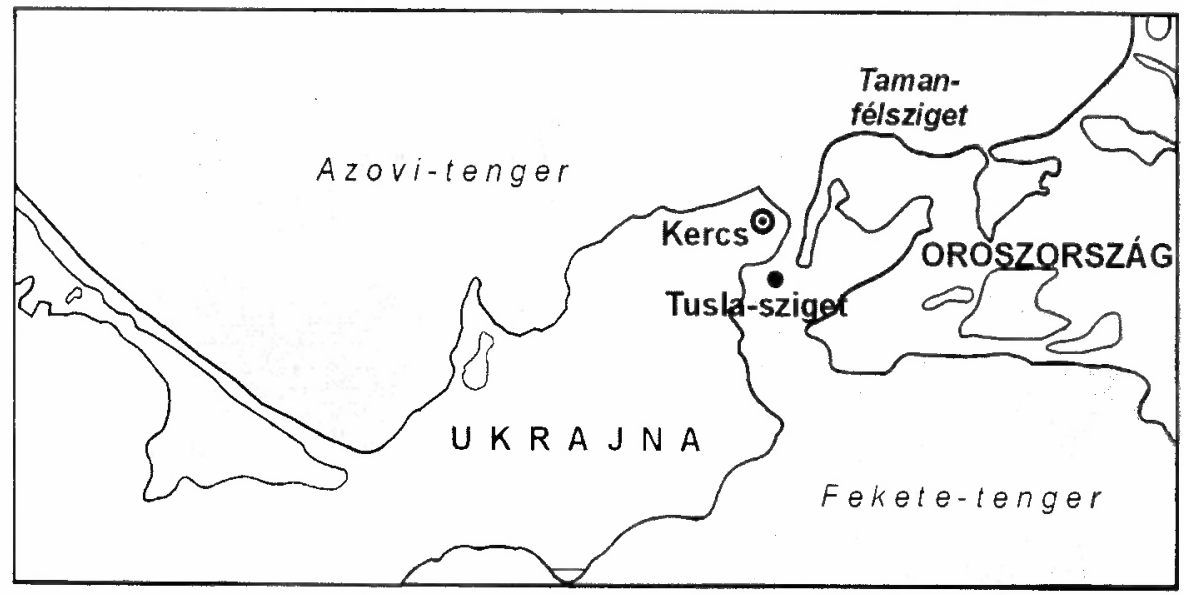

Szerkesztette: Erdősi. 
Erdősi Ferenc: Oroszország nemzetközi közlekedési infrastruktúráinak kényszerei, globális és regionális szerepei. Tér és Társadalom, 19. 2005. 1. 1-20. p.

\section{Saját kikötöfejlesztések és tranzit korridorok mint a nemzeti és a globális gazdaság kihívásaira adott infrastrukturális válaszok}

Oroszországot a politikai változások az 1990-es években kettős feladat elé állították a közlekedési infrastruktúra-fejlesztések súlypontjainak meghatározásakor:

- saját területén hozza létre a megfelelő tengeri kikötői kapacitást, számolja fel a szomszédos tranzitországokra való ráutaltságot, szüntesse meg az ebből adódó nemzetbiztonsági, külgazdasági kockázatot (nemzeti szempont);

- két kontinensre való kiterjedésének előnyét kihasználva transzkontinentális korridorok létesítésének felvállalásával tranzit összekötő kapocs (Landbridge) szerepet játsszon a világgazdaság meghatározó központjai, illetve más régiók között, amelyek a globális gazdaságba való betagolódását is szolgálják (a globalizációs kihívásoknak megfelelés szempontja).

E két feladat egy közös rendszerben valósítható meg, mivel a tranzitkorridorok ideális végpontjainak egy részét az új tengeri kikötők alkotják.

\section{Az új kikötöi kapacitások allokálása}

Az orosz kormány már 1993-ban nagyszabású kikötőfejlesztési programot indított be, amelynek elsősorban a stratégiai fontosságú olajkivitel akadálytalanná és olcsóbbá tétele volt a célja. A megvalósítás azonban a 21 . századig csak igen vontatottan haladt előre, részben a magánbefektetésekhez füzött, de nem megalapozott remények (a magánvállalkozási formában kezdödött építkezések csődje utáni viszszaállamosítások), részben a balti országok csővezeték szakaszainak és olajkikötöinek üzemeltetésében részt vevő orosz vállalkozók ellenérdekeltsége - valamint helyenként a környezetvédők tiltakozása - miatt (Radloff 2004).

A kormányzat azt a célt tủzte ki, hogy tíz éven belül az Oroszország által keltett évi 280-300 millió tonna kikötói forgalomból csupán 5 millió tonna maradjon a külföldi kikötökben. A hatékonyság érdekében a fejlesztési program az exportpiacokhoz legközelebb levő Keleti-tenger orosz kézen maradt partszakaszaira összpontosított. (A legnagyobb közvetlen destináció Rotterdam. E hubra a Keleti-tenger sekélyvizü kikötőiböl max. 45-70 ezer tdw nagyságú hajókkal jut el az olaj - évente ma már több mint 40 millió tonna -, de onnét a gazdaságosság érdekében már 250-350 ezer tdw raksúlyú szupertankerek viszik tovább az Egyesült Államokba, sỏt a TávolKeletre Japánba, Kínába, Tajvanba, Dél-Koreába stb.) Új kikötök kizárólag Szentpétervár tágabb térségében, a Finn-öböl (észt és finn határ közötti) partján, továbbá a Kalinyingrádi exklávéban épültek/nek. A Barents-, Fehér-, Azovi-és Feketetenger, továbbá a Csendes-óceán partján inkább csak a meglevö kikötök továbbfejlesztésére, bövitésére törekednek. 
Erdősi Ferenc: Oroszország nemzetközi közlekedési infrastruktúráinak kényszerei, globális és regionális szerepei. Tér és Társadalom, 19. 2005. 1. 1-20. p.

A Finn-öböl keleti végén (a szigetektöl eltekintve) mintegy $370 \mathrm{~km}$ part tartozik Oroszországhoz, amelyből kb. $40 \mathrm{~km}-\mathrm{t}$ tesz ki a több mint 4 milliós lakosságú szentpétervári agglomeráció, de számos kisebb város is sok helyet foglal el a partból. A szabad területeket a városi lakosság - meglehetösen extenzív módon - rekreációs/szabadidős célokra is használja. A Néva-torkolati Szentpétervár kikötője a sekély, eliszaposodott öbölben csak a bevezetó tengeri csatorna folytonos kotrásával üzemeltethető; bővítését helyhiány nehezíti.

E kultúrmetropoliszban környezeti és forgalmi szempontból a korszerübb kikötői funkcionális struktúra kialakítása az elsőrendü cél. Ezt szolgálja az olajkikötő kitelepítése, a fakikötő részleges kitelepítése és a konténerkikötő bővítése. 2004-ben Szentpétervár forgalma már közel fél millió TEU ${ }^{1}$. A folyamatos fejlesztések középtávon 1,35 millió TEU, tíz év múlva 3,5 millió TEU kapacitást teremthetnek (Radloff 2004). Ma még azonban Szentpétervárt a Keleti-tengeren megelözi Stockholm, Helsinki pedig hasonló forgalmú.

Az új kikötők közül a Finn-öböl déli partján levő Uszty Luga-t 1993-ban évi 35 millió tonna ömlesztett és darabáru, valamint konténer forgalomra tervezték. A többször megszakított és időközben kisebb kapacitás teremtéséhez igazodó építkezés első lépcsője fejeződött be (évente 4 millió tonna szibériai szenet átrakó, továbbá egy vegyes áru terminállal), 2006-ra készuil el a Németországba közlekedő vasúti/közúti jármủveket szállító komp terminálja. A konténerterminál távlatilag 500 ezer TEU kapacitásúra tervezése egyelőre túlzottnak tủnik, de nem lehetetlen, hogy valóban lesz rá igény, ha Oroszország feldolgozóipara strukturális váltás után talpra áll, illetve, ha a kikötő a Távol-Kelet-Nyugat-Európa Landbridge egyik rangos tengeri átrakóhelyévé válik. Uszty Luga tehát erősen diverzifikált struktúrájú kikötőkomplexum. Ezzel szemben a közeli Vistina mellett (4. ábra) csupán egy évi 16 millió tonna kapacitású olajterminál létesül (Mehr Öl... 2003).

Az északi parton, Primorszkban, ugyan szintén 1993-ban kezdödtek meg a munkálatok, de csak a századfordulón gyorsultak fel. Putyin személyes felügyelete mellett mindössze 18 hónap alatt 2001-ben készuilt el az évi 12-14 millió tonna kapacitású (de 2004-ben még csak alig 5 millió tonna forgalmú), az országos hálózatból kiágazó $366 \mathrm{~km}$ hosszú csővezetékkel táplált olajterminál. Az alig 30 km-rel távolabbi Vüszocknál 2005-re elkészülỏ új, évi 13 millió tonna (2012-re 25 millió tonnára bővítendő) kapacitású olajterminálon kívül a szentpétervári agglomeráció hagyományos kikötőinek (Lomonoszov, Kronstadt, Petrodvorec stb.) fejlesztése nyomán izgalmas jövöjü kikötörégió van kibontakozóban. Gazdaságosságuk javulásához nagyban hozzájárul a szinte mindegyikhez vezető bejárati csatornák mélyítése, amely lehetôvé teszi majd a nagy (80-250 ezer tdw) hajók rakodását, ezáltal azt is, hogy az olaj közvetlen járatokkal jusson el a távoli földrészek felhasználóihoz. Oroszország első számú kikötỏkomplexumának éppen a télen csak költségesen elérhetó tengerpartra felépítése a természeti viszonyok és a külkereskedelmet optimálisan szolgálni képes tengeri útvonalak közötti kompromisszum által létrejött szükségmegoldás, mert az orosz gazdaság ,magtérségéhez” (a Volgográd-MoszkvaSzentpétervár-Nyizsnij-Novgorod háromszöghöz) képest északkeletre fekszik. 
Erdősi Ferenc: Oroszország nemzetközi közlekedési infrastruktúráinak kényszerei, globális és regionális szerepei. Tér és Társadalom, 19. 2005. 1. 1-20. p.

TÉT XIX. évf. 2005 - 1

Oroszország nemzetközi ...

9

\section{4. ÁBRA}

Az új orosz kikötők a Finn-öbölben

(The New Russian Harbours in the Gulf of Finland)

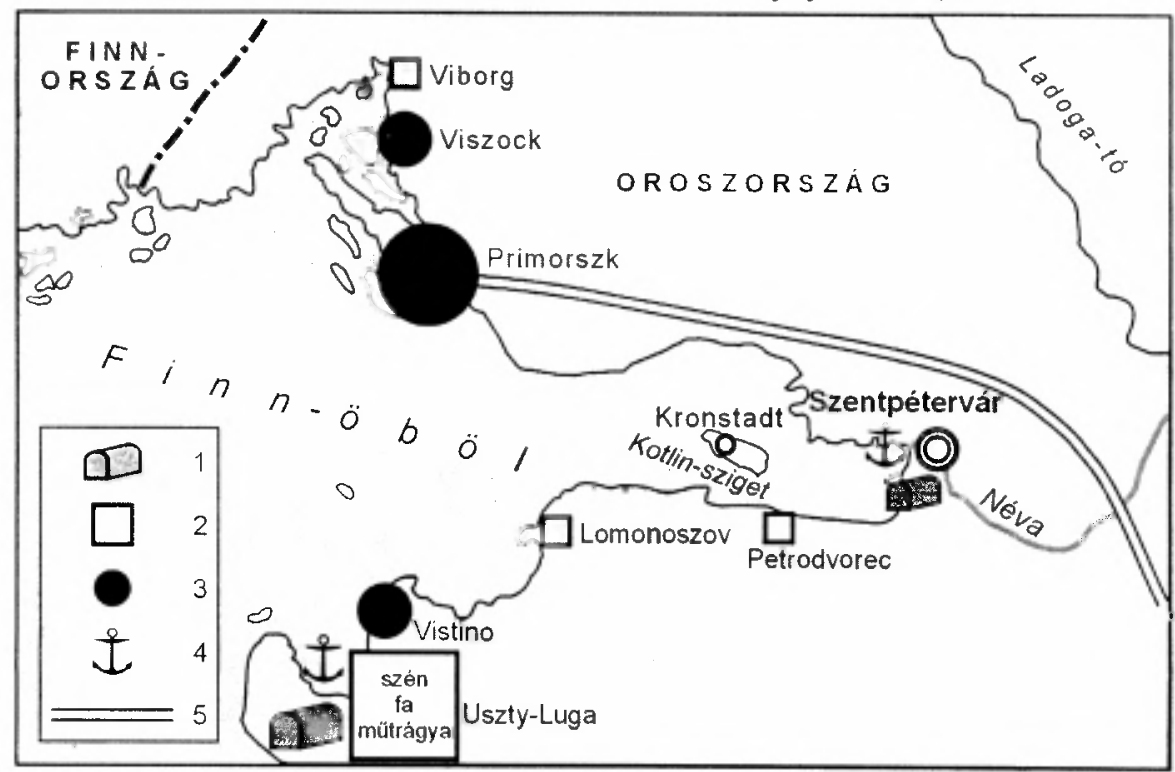

Jelmagyarázat:

1) új és továbbfejlesztett konténer terminálok; 2) vegyes ömlesztett áruk kikőtője; 3) olajterminál; 4) nemzetkỏzi komphajók kikötője; 5) olajvezeték.

Szerkesztette: Erdősi.

E szempontból (az európai és azon keresztül a nyugati hemiszféra elérése szempontjából) a kalinyingrádi exklávé jóval kedvezőbb fekvésű, azonban az idegen környezet miatt kiépítése nagyobb politikai kockázattal jár. Ennek ellenére Oroszország igyekszik a benne rejlő lehetőségeket kihasználni, mégpedig a hadászati célokat szolgáló kikötői területek - a csak $30 \mathrm{~km}$ hosszú tengeri csatornán elérhetö Kalinyingrád, de föként a tenger felöl könnyebben elérhetö Baltijszk - infrastruktúrájának konverziójával (polgárosításával). Azonban a Szentpétervár térségiekhez képest az itteni kapacitások igen szerények. Kalinyingrádban pl. 2003-ban mindöszsze 3,3 millió tonna vasúton érkezett olajat töltöttek hajókba (Zuwächse... 2004). A kalinyingrádi kikötőhármas egyéb forgalmának $85 \%$-át teszik ki az orosz, kis részben belorusz és ukrán exportáruk, amelyek közül a legnagyobb hányadot a nyersvas, vasáru, mütrágya és élelmiszeripari termékek képviselik. (A célországok közül kiemelkedő Németország, a Benelux országok, Spanyolország súlya [Kaliningrad moniert... 2004]).

Az orosz kikötök gazdálkodásukat azzal is eredményesebbé kívánják tenni, hogy Beloruszia, Ukrajna, söt Kazahsztán, Közép-Ázsia számára is akarnak szolgáltatásokat nyújtani, illetve szállítmányaikat a balti országok és Finnország kikötőiből átterelni. E célt az Orosz Vasutak (RZD) által 2003-ban bevezetett kettös tarifa- 
Erdősi Ferenc: Oroszország nemzetközi közlekedési infrastruktúráinak kényszerei, globális és regionális szerepei. Tér és Társadalom, 19. 2005. 1. 1-20. p.

rendszer is szolgálja, mely az orosz kikötökhöz képest az idegen kikötők felé (ill. visszafelé) tartó árukat két-háromszor drágábban szállítja, mint a saját kikötők felé (Gegenwind... 2003). E pozitív diszkrimináció mellett egyes balti országok negatív diszkriminácioja (az orosz áruk tranzitjának és tengeri átrakásának drágítása) is hozzájárult az orosz külkereskedelem tengeri kikötők szerinti megoszlásában bekövetkezett eddigi változásokhoz (1. táblázat), amelyek a következö években várhatóan felgyorsulnak.

\section{TÁBLÁZAT}

Az orosz áruk keleti-tengeri kikötökben való rakodásának alakulása országonként 1999 és 2003 között

(The Development of Goods Loading in the East Russian Harbours by Countries, 1999-2003)

\begin{tabular}{lcc}
\hline \multirow{2}{*}{ Ország kikötöi } & \multicolumn{2}{c}{ Részarány } \\
\cline { 2 - 3 } & 1999-ben & 2003 -ban \\
& $\%$ & $\%$ \\
\hline Oroszország & 26 & 36 \\
Lettország & 34 & 24 \\
Litvánia & 15 & 15 \\
Észtország & 25 & 25 \\
\hline
\end{tabular}

Forrás: Radloff 2004.

Oroszország európai tengeri kapui közül az Északi-jegestenger részét alkotó Barents- és Fehér-tengeri kikötők fejlesztése már jóval kevesebb figyelmet kapott

- föként a világkereskedelem meghatározó piacaitól félreeső fekvésük, így a Nyugat-Európától való nagy távolság,

- az ország gazdasági központjától való távolságuk, megközelítésük kedvezótlen feltételei, és

- részben (a Fehér-tenger esetében) üzemeltetésüknek a több mint fél évig tartó jég általi szezonalitása miatt.

Alapvetỏen két nagyobb kikötö jöhetett számításba az ország kikötőfejlesztési koncepciójának megvalósításakor, Murmanszk és Arhangelszk. Azonban a jelenlegi, egyenként csupán évi néhány millió tonnát elérö (föként szén-, apatit- és fakivitelböl álló) forgalmuk lényeges növelésére csak akkor lenne mód, ha a nyugatszibériai olajmezőktől idevezető $1500 \mathrm{~km}$ hosszú nagyteljesítményü (80 millió teév) olajvezeték megépülne (Bau des Murmansker... 2004).

Az orosz kézen maradt fekete-tengeri kikötök forgalma sem közelíti meg a Szentpétervár környékiekét, mert távol fekszenek a világkereskedelem nagy (legközelebb a Földközi-tengeren $\mathrm{Ny}-\mathrm{K}$ irányban átvonuló) tengeri útjaitól. A viszonylag legéletképesebb Novorosszijszk forgalmát visszafogja hátországában, a Csecsenföldön előállt instabil politikai/gazdasági helyzet, amely a kömyező térségeket is kedvezötlenül befolyásolja. Konténerforgalma 2003-ban így is elérte a 88,5 ezer TEU-t, de a 300 ezer TEU kapacitás eléréséhez lényegesen javulnia kell a hátországi viszo- 
Erdősi Ferenc: Oroszország nemzetközi közlekedési infrastruktúráinak kényszerei, globális és regionális szerepei. Tér és Társadalom, 19. 2005. 1. 1-20. p.

TÉT XIX. évf. 2005 日 1

Oroszország nemzetközi ...

nyoknak. Rosztov és az elökikötőjének tekinthető Taganrog (1. ábra) évi forgalma meghaladja a 20 millió tonnát (www.cfto.css-mps.ru).

A Csendes-óceán mellett Vlagyivosztok mintegy 60 évig zárt katonai területként nem válhatott igazán kereskedelmi kikötővé (www.vmtp.ru). A hegyek közötti mélyvizü Nahodka elsősorban az olajexportot szolgálja, a szük tengerparton alig bỏvíthető. Ezért tỏle néhány kilóméterre 1974-ben létrehozták a mindenféle áru rakodására alkalmas Vosztocsni kikötőt. Oroszország távol-keleti kapujaként forgalma gyorsan növekszik (2004-ben 30\%-kal), de így is csak 19,8 millió tonna (ebböl 14 millió tonna szén, 4,5 millió tonna olaj, továbbá mütrágya export). Konténerforgalma (260 ezer TEU 2004-ben) alapján viszont már ez a második az orosz kikötök közül (www.vics.ru).

\section{Az orosz kikötöfejlesztések kárvallottjai}

Az 1980-as években a Szovjetunió keretein belül a három balti ország a mögöttes szláv térség számára nagy előnyökkel járó gateway szerepet töltött be. A rajtuk keresztül tranzitált áruk értéke elérte a térség nemzeti jövedelmének 60\%-át, és a lakosság 8-10\%-a valamilyen módon az orosz tranzitból élt. Itt építették ki a Szovjetunió legnagyobb kapacitấú, saját kikötőkben véget érö olajvezetékeit, és az Oroszország felöl a balti kikötỏkig tartó vasúti fövonalak, föutak a legjobban kiépítettek közé tartoztak (Erdösi 2000). A baltikumi kikötök tehát olyan szerepet töltöttek be a keleti szláv térség számára, mint az északi tengeri ARA kikötők (különösen Rotterdam) Nyugat-Európa/Németország, sőt Közép-Európa számára.

Bár az 1990-es években a súlyos gazdasági krízis nyomán a szovjet utódállamok külkereskedelme erősen visszaesett, azonban a balti kikötőknek sikerült megőrizniük viszonylagos jelentőségüket azzal, hogy Oroszország nyugati viszonylatú áruforgalmának a 76\%-a, Belorusszia, Ukrajna hasonló forgalmának 5-12\%-a (összesen közel 70 millió tonna) rajtuk keresztül áramlott 1997-ben. Ugyan a balti országok attól való félelmükben, hogy a tranzit forgalom orosz kikötők felé átterelődése nagy bevételektől fosztja meg öket, már az 1990-es évek vége felé meghúzták a vészharangot, egészen 2003-ig nem volt érezhetö az egyértelmü forgalomcsökkenés. Igazán érzékeny visszaesés csak Ventspils kikötőjét sújtotta, ahová a megdrágult tranzitszállítás és kikötői díjak miatt 2000-től egyre kevesebb olaj érkezett, 2003-ban pedig elzárta a csapot az orosz Transzneft csővezetékes szállító társaság (KulkeFriedler 2003). Tallinban és más kikötőkben viszont a legutóbbi időkben is stagnált, söt valamelyest nőtt a forgalom.

Fordulat igazán 2003/2004-töl következett be, amikor már beüzemeltek az új orosz kikötök, és képesek voltak felvenni az egyre dinamikusabbá váló áruexport növekményének nagyobb hányadát. 2004 nyarától egyértelmüvé és általánossá vált a balti országokban és Finnországban az orosz tranzit volumenének visszaesése.

A kárvallott országok azonban többféle módon is igyekeznek e folyamatot lassitani. Több kikötő mérsékelte a szolgáltatási díjakat, hogy megtartsák orosz ügyfeleiket. Klajpeda a közeli Kalinyingráddal egyezményt kötött az üzleti együttmüködésre, közös transzeurázsiai irányvonatok indítására, a nyugati piacokon való közös 
Erdősi Ferenc: Oroszország nemzetközi közlekedési infrastruktúráinak kényszerei, globális és regionális szerepei. Tér és Társadalom, 19. 2005. 1. 1-20. p.

fellépésre (Zuwächse... 2004). Nagy a valószínüsége annak, hogy a Finn-öböl déli partján épült orosz kikötők és a közeli észt (kiváltképpen Tallin térségi) kikötöcsalád - Muuga, Paljassaare, Tallin - között a kölcsönös érdekek alapján sikerül kialakítani megfelelő kooperációt. Realitása igazán a funkcionális struktúraváltásnak van. Azaz, a tömegáru forgalom várhatóan erős csökkenéséből származó bevételkiesést a jobban fizető, nagyobb fajlagos értékủ darabáruk és konténeres áruk forgalmának növelésével, új logisztikai szolgáltatások bevezetésével lehet nagy mértékben ellensúlyozni, amelyekre az oroszok továbbra is vevök.

A 2004-ben körvonalazódó kikötö fejlesztési tervek arra vallanak, hogy a balti országok a verseny kiéleződése miatt nem estek letargiába, a minöségi és hatékonyabb szolgáltatások érdekében müszakilag tovább fejlesztik meglevö kikötöiket, korszerủbb terminálokkal, logisztikai központokkal kiegészítve javítják pozíciójukat. Söt, Litvánia új kikötöt is építeni akar a parti üdülöhelytỏl, Palengától északra, 13 km-re. Áruátrakás mellett az olajátrakással kapcsolatos környezetvédelmi technológiák $\mathrm{K}+\mathrm{F}$ központja is lesz ( $D V Z 23.11 .2004)$.

Ventspils a kieső olajtételeket a szárazáru forgalom növelésével (máris a világ egyik legnagyobb nitrogén mútrágya exportőre, és kiemelkedik a brazil gyümölcslé koncentrátumok Oroszország felé továbbításában), a Baltikumban letelepedô nyugat-európai, föként német termelö vállalatok és hipermarketek szállítási igényeinek újabb kompjáratok nyitásával (hetente 5 RoRo járat a svédországi Nynashamnba, 2 járat Lübeckbe) való kielégítésével igyekszik ellensúlyozni. Sokat remélnek az országban EU segítséggel megvalósuló 4 különleges gazdasági övezettől. A kikötői szektorbeli struktúraátalakulás folyamatába illeszkedik a kikötölogisztikai/kikötő üzemgazdasági képzést nyújtó új föiskola, tengertani kutatóintézet, azaz az alaptevékenységet támogató szellemi infrastruktúra létrehozása is (Kulke-Friedler 2003). Sokat várnak a kazahsztáni gabonát, üzbegisztáni gyapotot hozó multimodális szállítási rendszerbe való bekapcsolódástól. A városgazdálkodás időben felismerte az új helyzethez való alkalmazkodás, a tercier/kvaterner szektor felé fordulás szükségességét.

A három balti ország eddig még nem volt képes egységes platformot teremteni az orosz közlekedéspolitikával szemben. A kedvezötlen következmények kivédése. vagy legalább mérséklése érdekében a saját érdekeik és lehetőségeik által motivált szinguláris reagálásokkal válaszolnak. Az alapvetỏen a versenyre alapozott piacgazdasággal természetesen ez a magatartás az adekvát.

A Keleti-tenger „fordulója” közelében levö Klajpeda (5. ábra) esélyei a legjobbak egy olyan nemzetközi áruforgalmi fordítókorong szerep betöltéséhez, amelynek a legrégibb múltú tengeri komp összeköttetése van német kikötőkkel, de ahonnét könnyen elérhetỏ Dél-Svédországtól Szentpétervárig a legtöbb keleti-tengeri kikötö is, amely felé áramlik a szárazföldön (a jövőbeni „Via Baltica”-n) észak és délnyugat felöl az áru, és amely kiindulópontja a Keleti- és Fekete-tenger közötti szárazföldi „hídnak”, az egész Európa nyugatról való megkerülését feleslegessé tevő, Iljicsovszk és Odessza kikötőibe tartó konténer és más szállítmányú irányvonatoknak. Klajpeda képes volt maga felé terelni a Beloruszia és a lett kikötők közötti forgalom nagy részét, olyannyira, hogy ma már a világra nyiló kapu szerepét képes játszani a fehéroroszok számára (Hafen Klaipeda ... 2003). 
Erdősi Ferenc: Oroszország nemzetközi közlekedési infrastruktúráinak kényszerei, globális és regionális szerepei. Tér és Társadalom, 19. 2005. 1. 1-20. p.

\section{5. ÁBRA}

Az önálló balti országok kikötöi

(The Harbours of the Independent Baltic Countries)

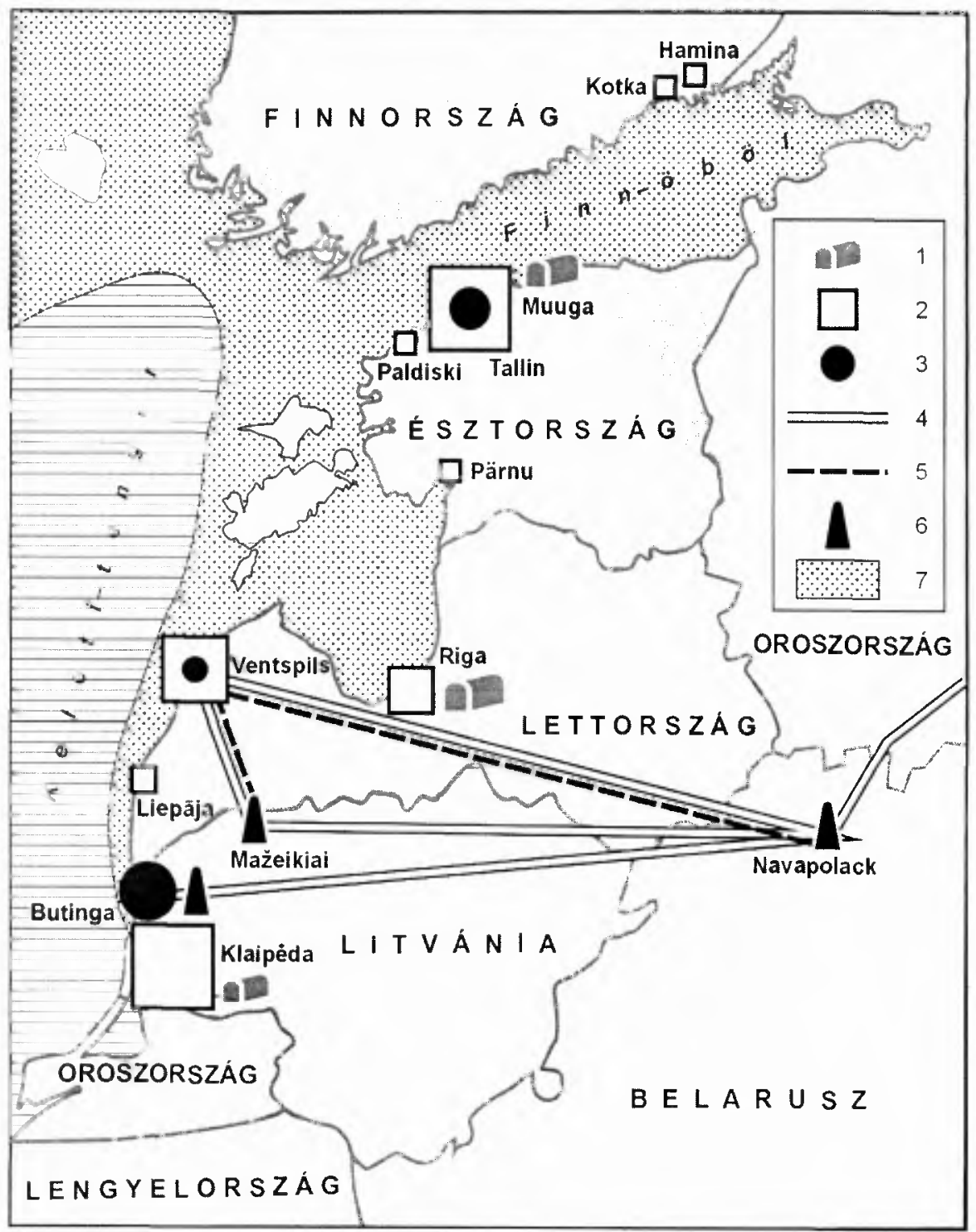

Jelmagyarázat:

1) továbbfejlesztett és új konténer terminál; 2) vegyes âru (túlnyomóan ömlesztett szárazáru) kikötő; 3) kőolaj és olajtermék terminál; 4) köolaj tranzitvezeték; 5) olajtermék vezeték; 6) olajfinomító; 7) télen jeges tengeröblök.

Szerkesztette: Erdösi. 
Erdősi Ferenc: Oroszország nemzetközi közlekedési infrastruktúráinak kényszerei, globális és regionális szerepei. Tér és Társadalom, 19. 2005. 1. 1-20. p.

14 Erdösi Ferenc

TÉT XIX. évf. 2005

A balti országokon kívül Oroszország küllkereskedelmi áruforgalmának nem elhanyagolható hányada dél-finnországi kikötökön át áramlott. Amióta Oroszország igyekszik a saját kikötöire alapozni, Finnország tranzitszerepe az orosz külgazdaság számára csökken (különösen 1999 óta). Így pl. a szentpétervári mütrágya átrakó terminál üzembe helyezése óta elmaradtak Finnországból ezek a tételek. Mindezek ellenére még 2002-ben is 5,6 millió tonna orosz export és import áru fordult meg a finn kikötőkben, és mintegy $70 \%$-uk Kotka, valamint Hamina termináljain összpontosult (Gegenwind... 2003). A balti országok belépésével Finnország elvesztette azt az unikális szerepét, hogy Oroszország egyetlen EU-tagország szomszédja, de helyzetének átalakulásában ennél jobban közrejátszott az orosz gazdaság által keltett tranzit forgalom szerkezetének a kevésbé tömeges szállítmányok felé való átalakulása. Még így is a Finn Vasutak teljes árutonna volumenének 40\%-át teszik ki az Oroszországból érkező, vagy oda küldött áruk (Kulke-Friedler 2003). Ezzel szemben a finn kikötök forgalmából meglehetősen szerény, csupán 6,5\%-os hányaddal részesül a (kevés kivétellel) orosz tranzit (Radloff 2004).

Annak ellenére, hogy a saját gazdasági érdekek okán nem felhőtlen a viszony Oroszország és Ukrajna között, a Fekete-tenger térségében még nem tapasztalható erös törekvés arra, hogy az ukrajnai kikötők felé áramló, évente 38-40 millió tonnát elérô tranzit jelentős részét orosz kikötők felé tereljék. Az orosz kormányzat újabban már inkább hajlik arra, hogy a kapacitásfelesleggel rendelkező ukrán kikötők használata a két ország közötti közlekedési integrációra alapozva gazdaságosabb, mint a - Novorosszijk (1. ábra) kivételével - rossz adottságú saját fekete- és azovitengeri kikötők fejlesztésének erőltetése (Sjögren 2004).

Ukrajna éppen az orosz, belorusz, sőt finn és skandináv tranzitárukra számítva az eddigiekhez képest rendkívül nagy kapacitású konténerterminálok létesítését tervezi. Iljicsovszkban a 2004. évi 190 ezer TEU forgalommal szemben 2010-re 2 millió TEU-ra növelik a kikötö kapacitását, de egy teljesen új óriás konténer kikötőt is terveznek Skadovszk közelében 9 millió TEU forgalomra méretezve. (Hamburg 2004. évi forgalma is csak 6,3 millió TEU volt.) Annak közelében egy ömlesztett és folyékony áru (szén, koksz, cement, olaj) kikötöt is terveznek 103,5 millió tonna forgalomra, melyet egy RoRo kikötö is kiegészítene (Sjögren 2004a). Részben a tranzitot is szolgálná az alapvetően a bilaterális áru- és személymozgás könnyítése érdekében hamarosan megépülő vasúti alagút a Kercsi-tengerszoros alatt, amely összeköti a Kubánvidéket a Krim-félszigettel. A benne elhelyezett csővezetéken jutna el a grozniji olaj Odesszába és olcsóbbá tenné a dél-ukrajnai finomítók olajellátását (Sjögren 2004c).

\section{A transzeurázsiai korridorok mint Oroszország globális és nagyregionális szerepét javitó infrastruktúrák}

Kedvezötlen klimatikus adottságai miatt a formálisan rendkívül hosszú tengerparttal rendelkezö Oroszország nem válhat igazi (maritim) tengeri hatalommá. E helyzetet ellensúlyozandó inkább szárazföldi elhelyezkedését kihasználva igyekszik 
Erdősi Ferenc: Oroszország nemzetközi közlekedési infrastruktúráinak kényszerei, globális és regionális szerepei. Tér és Társadalom, 19. 2005. 1. 1-20. p.

TÉT XIX. évf. 2005 - 1

Oroszország nemzetközi ...

globális pozícióra szert tenni Ny-K és észak-dél irányú transzeurázsiai korridorok kiépítésével, forgalmi szerepük növelésével és metszéspontjaikban globális logisztikai központ/fordítókorong kialakításával. E megakorridorok a globálison és nagyregionálison kívül többféle nemzeti szintü szerepet is betölthetnek:

- az óriási kiterjedésü, sok esetben a helyi, területi érdekeik szerint müködő régiók közötti együttmüködést, végső soron a birodalmon belüli kohéziót szolgálják,

- a belföldi, valamint export/import forgalom intenzitása több szakaszon együttesen sem éri el azt a szintet, amely elegendő bevételt biztosítana a költségekkel szemben, ezért a kapacitás kihasználását lényegesen javító, a bevételeket, a gazdaságosságot növelö tranzitra mindenképpen szükség van, különösen a Transsib fenntartásához; ezen felül

- a korridorok nem annyira a bérfuvarozásból származó közvetlen többletbevételekkel, mint inkább az általuk vonzott tỏkével nélkülözhetetlen területfejlesztő, térszerkezet formáló erőnek bizonyulnak.

\section{A Transsib és lehetséges versenytársai az óceánok közötti szállításban}

Oroszországnak eddig leghatékonyabban a nyugat-kelet irányú, a finn/baltikumi/ belorusz/ukrán határtól a távol-keleti kikötőig tartó korridort sikerült helyzetbe hoz$n i$, amely (a nyugati folytatásait is figyelembe véve) Nyugat-/Észak-Európa és Kelet-Ázsia között jól kiépített kétvágányú, villamosított nagyteljesítményü vasútvonalat, és legújabban (a Csita-Habarovszk szakasz megépuiltével) már gépkocsikkal járható utat is tartalmaz (Transsib-Straße „Amur”... 2004). A tehergépkocsi azonban nem versenytársa az orosz állam területén legalább 10 ezer $\mathrm{km}$ hosszú, a nyugati FÁK-államok ugyancsak széles nyomtávú pályáin további ezer km utat nyomtáv váltás nélkül 10-13 nap alatt megtenni képes irányvonatoknak. A Transsib vonalon 1964 óta folyik tranzitszállítás, újabban szinte már teljesen konténeres áru formájában. A forgalom az 1980-as években érte el az első csúcspontját, akkor elsősorban Japán mutatta a legnagyobb érdeklődést iránta. A Szovjetunió felbomlása utáni zavaros viszonyok és a recesszió együttes hatására a korridor nagyban vesztett jelentőségéből, a japán szállíttatók nagy része elpártolt a Transsibtől. Az áruk biztonságának garantálása, a szállitási idö csökkentése és az idóközben ipari dömpingárukat exportáló Dél-Korea, majd Kína nagy volumenü szállitási igényei újból dinamizálták a forgalmat (Pechterew-Scharapow 2001).

Miután Finnország a keleti irányú közlekedésben Nyugat-Európa, kisebb részben Észak-Amerika számára egészen különleges súlyú nemzetközi logisztikai központtá nötte ki magát, a Transsib konténerforgalmának ujjabban a 80\%-át a Finnország és Dél-Korea/Kína között áramló áruk teszik ki, és csak a kisebb hányadát a közvetlen nyugat- és közép-európai, vagy a - Fekete-tenger felé kiágazó ágával - mediterrán illetékességü áruk (www.dvtg.ru).

Annak ellenére, hogy mind a szállítási idő, mind a fuvardíj tekintetében a tengeri úthoz képest a Transsib kedvezöbb alternatíva, erre az orosz közlekedési miniszter 
Erdősi Ferenc: Oroszország nemzetközi közlekedési infrastruktúráinak kényszerei, globális és regionális szerepei. Tér és Társadalom, 19. 2005. 1. 1-20. p.

(Fadejev) nyilatkozata szerint a Kelet-Ázsia-Európa közötti (össztonnasúly) forgalomnak mindössze alig az 1\%-a jut, 99\%-a az Ázsiát délről megkerülö (szuezi) tengeri úton éri el desztinációját (illetve mintegy $0,1 \%$-a jut a légi útra).

Elvileg az északi-jegestengeri hajóút (a globális hajózás „Északkeleti Átjárója”) is versenytársa lehetne a Transsibnek a tranzitforgalomban. A Szovjetunió az Egyesült Államoknak az Arktiszról való kiszorítására törekedve létre akarta hozni az Északi-sarkon át vezető, a part mentinél 1300 km-rel rövidebb hajóutat. (Az USAval szemben a Szovjetunió nem csak katonai nukleáris tengeralattjárókkal, hanem 1977-ben az „Arktika” jégtöröhajóval is elérte az Északi-sarkot [Armstrong 1987]). Azonban a politikai viszony javulásával e terv elvesztette aktualitását, és ma az orosz politika csak a part menti vízi út fejlesztésére szorítkozik. Ennek a nagyon költséges vízi útnak a fö rendeltetése, hogy a szibériai olaj-, szén- és ércbányászatot kiszolgálja, föként Murmanszk, ritkábban a Távol-Kelet felől müszaki berendezések, közszükségleti cikkek folyótorkolati kikötőkbe juttatásával, részben a kitermelt olaj, ásványi nyersanyagok elszállításával. Mivel a Jenyiszej-, méginkább a Léna-torkolattól keletre a legnehezebb a hajózás, az Északi-hajóút teljes hosszában rendszeres hajózás, folyamatos tranzitszállitás nem folyik, csak idönként az átmenetileg kedvezöbb jégviszonyok idején jutnak el a Bering-szorosig hajókaravánok. Végső soron az Északihajóút igazából orosz belföldi szállitási vonal, melynek azonban áttételesen a külkereskedelemben is van szerepe. (Ma még föként oly módon, hogy az Észak-Szibériából induló kisebb tankerekböl Murmanszkon töltik nagyobb hajókba az olajat, melyek föként Rotterdamba, illetve az USA és Kelet-Ázsia kikötöibe tartanak.)

Az. Északi-hajóút globális/interkontinentális jelentösége növekedhet, ha a globális felmelegedés következtében az Arktisz jégtakarója tovább zsugorodik, és így kisebb ráfordítással a nyári hónapokban jégtörök nélkül végig hajózható lesz.

A Transsib alternatívái igazából a tőle délre, Közép-Ázsián és a Közel-/KözépKeleten át Kína partjaitól Nyugat-Európába vezető pályák lehetnek. Alapvetően Kinától függ, hogy lesz-e reális versenytársa az oroszországi transzeurázsiai pályának.

Kína óriási áruexportjának az atlanti partokig vasúton való eljuttatása kardinális igény, amit minden valószínüség szerint csak több útvonalváltozat használatával tud optimálisan kielégíteni.

- A hagyományos Transsib és

- az azt kiegészítő északnyugati bimodális (vasúti/tengeri) interkontinentális - szemiglobális, Narvikon át Észak-Amerika keleti partvidékéig (Boston és Halifax kikötőkig tartó) korridor (6. ábra) használatának feltétele az Oroszországgal fenntartott korrekt politikai viszony.

- Az Oroszországot megkerülö bármilyen vonallánc viszont versenypályaként arra késztetheti az orosz vasutakat, hogy tovább korszerüsítsék a tranzitpályákat és olcsóbbá tegyék a szolgáltatásaikat.

Kazahsztán és Kína gazdasági elönyöket remél a Sárga-tenger parti Lienjünkang kikötőböl induló, Kazahsztánon, Türkmenisztánon, Iránon, Törökországon (a Boszporusz alatt már épülö 14 km hosszú alagutat is felhasználva) átmenő, Európában 
Erdősi Ferenc: Oroszország nemzetközi közlekedési infrastruktúráinak kényszerei, globális és regionális szerepei. Tér és Társadalom, 19. 2005. 1. 1-20. p.

TÉT XIX. évf. 2005 — 1

Oroszország nemzetközi ...

17

folytatódó és egészen Hamburgig tartó transzeurázsiai vasúttól. Teljesen új pályát csak keveset kellene építeni, viszont normál nyomtávúvá kellene átépíteni a Kazahsztánon és Türkmenisztánon átvonuló több ezer km-es részeit. E pályalánc néhány nappal rövidítené Peking-Moszkva viszonylatban is a menetidőt, és a Transsib kiiktatásával olcsóbbá tenné Európa elérését is (Zholy 2004).

E pályaláncban nyilvánvalóan benne van az orosz vasutakra való rászorultság csökkentésének, sőt megszüntetésének lehetösége. Elvitathatatlan elönye, hogy a Csendes- és Atlanti-óceán közötti szállításokat nem terhelnék a nyomtávkülönbségböl adódó költségek.

Végső soron a monopolhelyzet megtörése alternatívákkal javíthatja a kínai/középázsiai áruk Európába, illetve Amerika atlanti partvidékére való exportjának logisztikai feltételeit. Az új vasútvonal lánc kiépítésének költsége csupán Kazahsztánban 5-7 milliárd USD. Kérdés, hogy belátható időn belül finanszírozható-e ez az újabb projekt. Erre csak akkor van reális esély, ha az ENSz Gazdasági Bizottsága és számos érintett, sőt más ország által támogatott Traseca (Új Selyemút) program modifikációjának és nem az eredeti projekt versenytárgyának tekintik. A Traseca Európát a bolgár/román tengerparton hagyja el, és a Fekete-tengeren, Grúzián/Azerbajdzsánon, a Kaszpi-tengeren, Türkmenisztánon, Üzbegisztánon át éri el Nyugat-Kínát. Kazahsztánon áthaladó változattól sem zárkóztak el tervezöi (Erdösi 1999).

\section{6. ÁBRA}

A Transsib és a többi transzeurázsiai korridor, valamint az Észak-Dél korridor (The Transsib, the Other Transeurasian and the North-South Corridor)

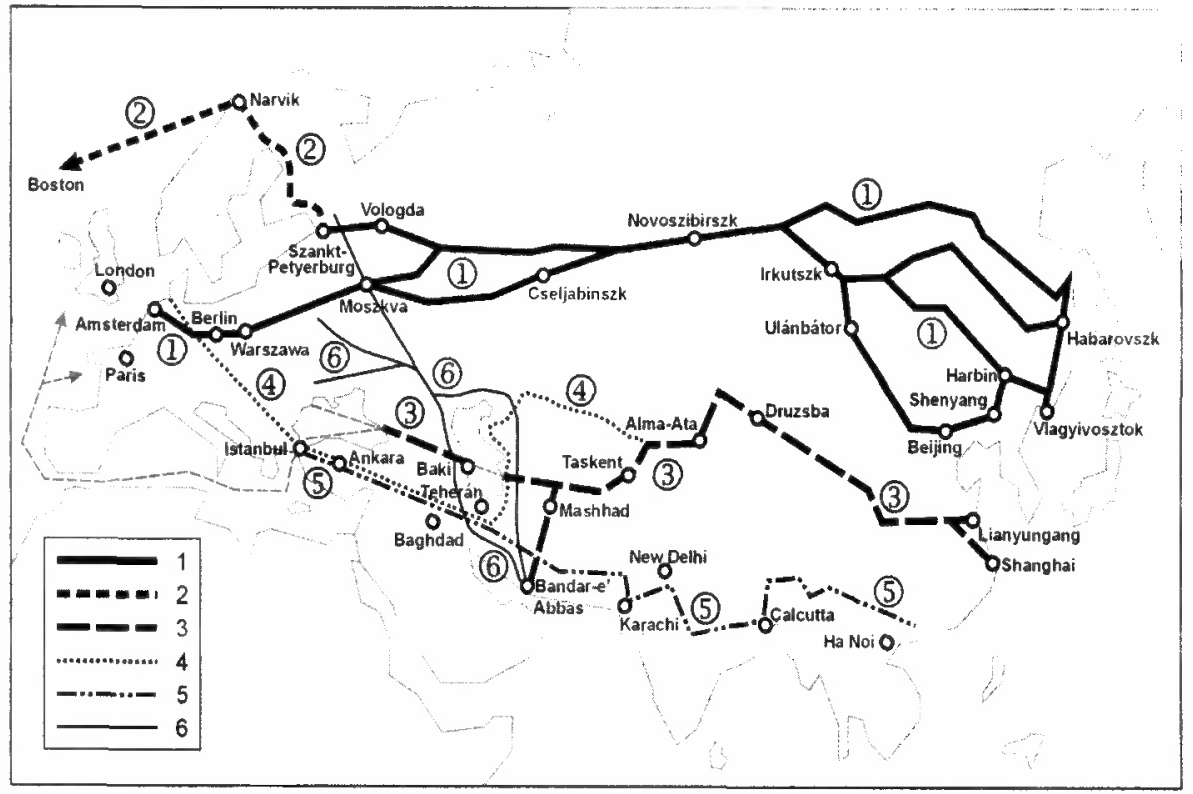

Szerkesztette: Erdösi. 
Erdősi Ferenc: Oroszország nemzetközi közlekedési infrastruktúráinak kényszerei, globális és regionális szerepei. Tér és Társadalom, 19. 2005. 1. 1-20. p.

\section{Az Észak-Dél korridor}

Oroszország külpolitikai aspirációiban mindig is elökelö helyen szerepelt a Perzsa-öbölbe való kijutás, a hagyományosan brit érdekszférához tartozó KözépKeleten való jelenlét. E törekvés az orosz kormánynak a Finnországot Oroszországon és Iránon át az Öböllel, valamint az indiai szubkontinenssel összekötö transzeurázsiai Észak-Dél korridor koncipiálásában és megvalósításában játszott meghatározó szerepében manifesztálódik. Az orosz elöterjesztést a Il. Nemzetközi Eurázsiai Közlekedési Konferencia 2000-ben elfogadta, és a létrejött (Irán és India által is támogatott) nemzetközi egyezményhez a III. Konferencián, 2001-ben már számos érintett, vagy csak közvetett hasznot remélö ország (Bulgáriától, Belorusziától Tadzsikisztánig, illetve Azerbajdzsántól, Szíriától Ománig) csatlakozott, vagy tett hozzájárulási nyilatkozatot, míg egészen távoliak (Lettország, Malaysia, Thaiföld, Dél-Korea) a részvételük lehetöségét mérlegelik (Slobodyanyuk 2004).

Az Észak-Dél Korridor oroszországi szakaszán folyami/vasúti kombinált szállitás, Iránban vasút, Bandar Abbaz (Hormuzi-tengerszoros) és India között a tengeri út jöhet számításba. A Kaszpi tágabb térségében több alternatívában gondolkodnak a tervezök. Az egyik nyugaton Azerbajdzsánon (illetve Örményországon) keresztül, a másik a Kaszpi vízi utat felhasználva (Mahacskala és föként Olja orosz kikötők. valamint az iráni Enseli kikötő között). Ezen felül Kazahsztán és Közép-Ázsia bekapcsolása érdekében a Kaszpit keletröl megkerülö alkorridornak is lehet létjogosultsága - a Türkmenisztán és Irán között 1998-ban teremtett vasúti összeköttetést (Tedzsen és Mashad között) is kihasználva. Oroszország céltudatosan fejleszti a korridorhoz tartozó vasúti fövonalait, és Olja konténerkikötöhöz vasúti szárnyvonalat épített (Containerterminal... 2003).

Az Észak-Dél Korridor az Európa (főként Északnyugat-Európa gazdasági „,magtérség") és Ázsia közötti viszonylatban a nyugat felöl (Beloruszián, Ukrajnán át) hozzácsatlakozó korridorral együtt a Szuezi-csatorna versenytársa lehet az értékesebb áruk konténeres szállításában. (A németországi Frankfurtból Iránba egy 40' [lábas] konténer fuvarköltsége tengeri hajóval 5670 USD-be kerül, viszont a létrehozandó korridoron csak 3600 USD lenne [Kooperation... 2000].)

\section{Összefoglaló következtetések}

A Szovjetunió messze legnagyobb utódállama, Oroszország, miután elvesztette szuperhatalmi pozícióját, gazdasági helyzetéhez képest erőn felüli, területileg és irányok szerint összpontosított infrastruktúra-építésekkel igyekszik a globális gazdaságba bekapcsolódni. E törekvés két, egymástól nem független mozzanatban nyilatkozik meg. Az egyik a megfelelö saját kikötöi kapacitás megteremtése a szomszédos országokbeli fizetett tranzittól való függőség felszámolása érdekében. A másik a világgazdaság nagy eröközpontjait összekötö nyugat-kelet irányú Keletitenger-Távol-Kelet (Transsib) korridor tranzitforgalmának, söt a kontinenst meghaladó jelentőségének növelése, valamint a közép-keleti muzulmán nagyrégió érde- 
Erdősi Ferenc: Oroszország nemzetközi közlekedési infrastruktúráinak kényszerei, globális és regionális szerepei. Tér és Társadalom, 19. 2005. 1. 1-20. p.

keit is szolgáló, de egyben az orosz külgazdaság számára rendkívül elönyös piacok elérését megkönnyítő (Északnyugat-Európa számára pedig Ázsiával költségtakarékosabb logisztikai vonalat teremtő) Észak-Dél Korridor kiépítése Finnország és a Perzsa-öböl között. E transz- és interkontinentális korridorok, valamint az eurázsiai fordítókorong müködése azonban nagymértékben attól függ, hogy sikerüll-e majd biztositani egyfelöl a korridorok szovjet utódállamokbeli/finnországi, másfelöl a csatlakozó közép-európai/skandináviai/közép-keleti/kelet-ázsiai szakaszainak müszaki interoperabilitását. Ezen felül e szemiglobális léptékü infrastruktúrák az általuk felfüzött, összekapcsolt területek közötti politikai viszonyokra erösen érzékeny rendszerek. Oroszország nyilvánvaló érdeke, hogy e nagy gazdasági hasznot ígérő infrastruktúrák müködtetése ne nélkülözze a korrekt együttmüködésre alapozott békés ,jó szomszédsági" kapcsolatokat. Kína külgazdasága számára ma nélkülözhetetlen az Oroszországon átvonuló tranzitpálya. Nem lehetetlen, hogy a délebbi, Közép-Ázsián át megépülö (végig interoperábilis) kelet-nyugati vasúti pályalánccal Kína megtöri az Orosz Vasutak monopolhelyzetét, központi szerepét az Atlanti- és Csendes-óceán közötti transzeurázsiai szállításban.

\section{Jegyzet}

${ }^{1}$ A TEU a konténerek egysége: 1 TEU $=20$ angol láb (foot) széles konténer 1 tdw $=1010 \mathrm{~kg}$ hordképesség.

\section{Irodalom}

Antal Z. (1983) A Szovjetúnió gazdaságföldrajza. Gondolat kiadó, Budapest.

Armstrong, T. (1987) Soviet ideas for pioneering shipping in the Central Arctic Basin. - Tismer, F.Ambler, J.-Symons, L. (eds.) Transport and economic development - Soviet Union and Eastern Europe. Osteuropa-Institut an der Freien Universität Berlin. Wirtschaftswissenschaftliche veröffentlichungen. Duncker und Humblot, Berlin. 175-184. o.

Bau des Murmansker Ölterminal - weiter ungewiss. (2004) - Deutsche Verkehrszeitung. 15. April.

Buchofer, E. (1995) Transport infrastructure in the Baltic States during the transformation to market economies. - Journal of Transport Geography. 1. 69-75. o.

Buchofer, E. (1998) Die Königsberger Insellage: Heikle Transitaufgaben für Polen und Litauen. Geographische Rundschau. 1.49-51. o.

Containerterminal am Kaspischen Meer eröffnet. (2003) - Deutsche Verkehrszeitung. 16. Oktober.

Deeg, L. (2004) Neue Hăfen braucht das Land. - Deutsche Verkehrszeirung. 20. März.

Erdősi F. (1999) Az új transzeurázsiai vasúti összeköttetések I-II. - Közlekedéstudományi Szemle. 7 241-248. 0.; 8. 281-285. o.

Erdősi F. (2000) Európa közlekedése és a regionallis fejlödés. Dialóg Campus, Pécs-Budapest.

Gegenwind für das Russlandsgeschaft. (2003) - Deutsche Verkehrszeitung. 04. Dezember.

Hafen Klaipeda sieht sich als Weißrusslands „Tor zum Weit”. (2003)-Deutsche Verkehrszeitung. 21. Oktober.

Johnson, C. (ed.) (1984) Russland. Centaur Press, London.

Kaliningrad moniert Transitsituation. (2004) - Deutsche Verkehrszeitung. 18. Mai.

Kooperation mit Iran beim Eisenbahnbau. (2004) - Deutsche Verkehrszeitung. 04. Mai.

Kulke-Friedler, Ch. (2003) Scharfer Wettbewerb. - Deutsche Verkehrszeitung. 22. November.

Mehr Öl via Primorszk. (2003) - Deutsche Verkehrszeinung. 22. Juli.

Pechterew, F.-Scharapow, S. (2001) Die Rolle Transsibirischen Eisenbahnmagistrale bei der Schaffung der internationalen Transportkorridore. - Zeitschrift der OSShD. 4-5. 19-24. o.

Radloff, M. (2004) Markt mit großem Potential. - Deutsche Verkehrszeitung. 04. Dezember.

Sjögren, M. (2004a) Container-Megaport gewinnt Kontur. - Deutsche Verkehrszeitung. 31. August. 11. o. 
Erdősi Ferenc: Oroszország nemzetközi közlekedési infrastruktúráinak kényszerei, globális és regionális szerepei. Tér és Társadalom, 19. 2005. 1. 1-20. p.

Sjögren, M. (2004b) Verkehrsintegration mit Russland angestrebt. - Deutsche Verkehrszeitung. 02. Oktober.

Sjögren, M. (2004c) Krim und Kuban soll ein Eisenbahntunnel verbinden. - Deutsche Verkehrszeitung. 02 . November.

Slobodyanyuk, L. (2004) Internationaler Transportkorridor „Nord-Süd”. - Zeitschrift der OSShD. 5-6. 1-5. o. Szerzố és cím nélküli rövid hír. (2004) Deutsche Verkehrszeitung. 23. November.

Transsib -Straße „Amur” dem Verkehr übergeben. (2004) - Deutsche Verkehrszeitung. 02. März.

Zholy, T. (2004) Kazachstan konkretisiert eurasisches Bahnprojekt. - Deutsche Verkehrszeitung. 02. September. 7.0.

Zuwäsche fur Kaliningrad. (2004) - Deutsche Verkehrszeitung. 15. Januar.

www.cfto.css-mps.ru

www.dvtg.ru

www.vics.ru

www.vmtp.ru

\title{
RUSSIA'S INTERNATIONAL TRANSPORT INFRASTRUCTURE CONSTRAINTS, GLOBAL AND REGIONAL ROLES
}

\author{
FERENC ERDÖSI
}

Russia, far the largest successor state of the Soviet Union, having lost its super power position is trying to integrate into the global economy by infrastructure developments beyond its means, concentrated geographically in a few directions. This effort is manifested in two, related measures. One of them is the construction of the country's own port capacities in order to eliminate the dependence on the transit paid to the neighbouring countries, the other is the increase of the transit traffic and even the global importance of the West-East (Transsib) corridor linking the great power poles of the world economy from the East Sea to the Far East, and the construction of the North-South Corridor between Finland and the Persian Gulf, serving the interests of the Muslim large region of the Middle East but also alleviating the access to the markets important for the Russian foreign trade (and establishing a more cost effective logistic line to Asia for Northwest-Europe). However, the operation of these trans- and intercontinental corridors and the Eurasian turntable depends to a large extent on whether the technical inter-operability of the sections in the Soviet successor states and Finland, and in the adjoining Central European/Scandinavian/Middle Eastern/East Asian parts of the corridor is provided. In addition, these infrastructures of semi-global scale are very sensitive to the political relations among the regions that they connect. It is a vested interest of Russia that the operation of these infrastructures, promising a high yield, should be built on "good neighbourhood" relations on the basis of correct co-operation. For the foreign trade of China, the transit tracks running through Russia are irreplaceable today. It is possible that the more southern railway chain of East-West direction to be built in Middle Asia (inter-operational in its whole length) will break the monopoly situation of the Russian Railways and their central role in the trans-Eurasian transport between the Atlantic and the Pacific Ocean. 